Review

\title{
Genetic Tools and Techniques for Recombinant Expression in Thermophilic Bacillaceae
}

\author{
Eivind B. Drejer, Sigrid Hakvåg, Marta Irla and Trygve Brautaset * \\ Department of Biotechnology and Food Science, NTNU: Norwegian University of Science and Technology, \\ 7491 Trondheim, Norway; eivind.b.drejer@ntnu.no (E.B.D.); sigrid.hakvag@ntnu.no (S.H.); \\ marta.k.irla@ntnu.no (M.I.) \\ * Correspondence: trygve.brautaset@ntnu.no
}

Received: 16 April 2018; Accepted: 3 May 2018; Published: 10 May 2018

\begin{abstract}
Although Escherichia coli and Bacillus subtilis are the most prominent bacterial hosts for recombinant protein production by far, additional species are being explored as alternatives for production of difficult-to-express proteins. In particular, for thermostable proteins, there is a need for hosts able to properly synthesize, fold, and excrete these in high yields, and thermophilic Bacillaceae represent one potentially interesting group of microorganisms for such purposes. A number of thermophilic Bacillaceae including B. methanolicus, B. coagulans, B. smithii, B. licheniformis, Geobacillus thermoglucosidasius, G. kaustophilus, and G. stearothermophilus are investigated concerning physiology, genomics, genetic tools, and technologies, altogether paving the way for their utilization as hosts for recombinant production of thermostable and other difficult-to-express proteins. Moreover, recent successful deployments of CRISPR/Cas9 in several of these species have accelerated the progress in their metabolic engineering, which should increase their attractiveness for future industrial-scale production of proteins. This review describes the biology of thermophilic Bacillaceae and in particular focuses on genetic tools and methods enabling use of these organisms as hosts for recombinant protein production.
\end{abstract}

Keywords: recombinant expression; thermophiles; Bacillus; Geobacillus; Bacillaceae

\section{Introduction}

Bacteria are widely used in science and industry as cell factories for production of recombinant proteins. The choice of bacterial host and expression system relies heavily on the origin and properties of the heterologous protein. Today, the most commonly used bacterial hosts for expression of heterologous proteins are the Gram-negative Escherichia coli and the Gram-positive Bacillus subtilis. E. coli is in many cases the most used host due to several advantages, including an extensively developed genetic tool box, well-known genetics and physiology, low-cost media, and rapid protein production in a short fermentation period [1]. However, this species also exhibits some limitations as the heterologous proteins are typically expressed intracellularly, which results in problems with formation of inclusion bodies and incorrect protein folding. B. subtilis, on the other hand, has become an industrial workhorse for recombinant protein production due to an easy cultivation, the products of its metabolism being generally recognized as safe (GRAS), ease of genetic manipulation, well-characterized expression systems, absence of significant codon bias, and exceptional ability to secrete heterologous proteins allowing cost-effective downstream processing. Lacking an outer membrane, $B$. subtilis can efficiently secrete recombinant proteins to the culture medium, therefore this bacterium is more suitable for the production of secretory recombinant proteins than E. coli $[2,3]$. Challenges in recombinant protein production in B. subtilis have typically been related to the activity of cell-wall-associated proteases interfering with folding of heterologous proteins in the interface between 
cell wall and extracellular space. This has later been ameliorated with the use of genome editing to remove the genes coding for interfering proteases [4-6]. Further work on B. subtilis to improve its properties as a host for heterologous protein production has been done, including Morimoto et al. (2008) demonstrating that a $20 \%$ reduction of genome size resulted in a proportionate increase in recombinant protein yields at the cost of lowered growth rates [7]. The status and advantages of recombinant protein production in B. subtilis has been reviewed thoroughly by Dijl and Hecker [8].

The successful application of $B$. subtilis as a host for the production of recombinant proteins has naturally spurred interest in exploring additional Bacillaceae for the same purpose, some of which belong to the group of thermophilic bacilli and geobacilli. Bacillaceae typically share several of the favorable traits described for B. subtilis. For example, most Bacillaceae species are nonpathogenic and free of exo- and endotoxins, which is particularly advantageous for production of pharmaceutical proteins [9]. Due to their cell wall composition, Bacillaceae display a remarkable ability to secrete recombinant proteins [10]. Nazina et al. (2001) reclassified several thermophilic Bacillus species into the new genus Geobacillus; in this review, we choose to treat both thermophilic Bacillus ssp. and Geobacillus ssp. as compatible systems for recombinant protein expression, and collectively refer to them as thermophilic Bacillaceae [11]. The boundary between bacterial mesophilism and thermophilism has earlier been suggested to lie in the temperature range $44-52{ }^{\circ} \mathrm{C}$ [12] and bacteria are generally classified as thermophilic if they have a temperature optimum above $50{ }^{\circ} \mathrm{C}$ [13]. Some strains of B. coagulans are normally cultivated below this threshold (i.e., $37^{\circ} \mathrm{C}$ or $40^{\circ} \mathrm{C}$ for B. coagulans DSM1, see Table 1), but are classified as thermophilic Bacillaceae in this review as strains with optimum growth temperatures above $50{ }^{\circ} \mathrm{C}$ also exist, e.g., B. coagulans 36D1 [14-16]. Facultative thermophiles are capable of growing at thermophilic temperatures after an adaptation phase at intermediate temperatures [12].

A general prerequisite for heterologous protein production in any microorganism is availability of functional genetic tools and gene delivery methods. Efficient protein production requires replicating plasmid vectors with constitutive and/or inducible promoters, strong ribosome binding sites, transcriptional terminators, selection markers, and functional reporter genes [17]. Genetic engineering in thermophilic bacteria presents certain specific challenges regarding stability and functionality of antibiotics, selection markers, and plasmid replication at elevated temperatures. Thermophilic Bacillaceae are currently not used for commercial production of heterologous proteins; however, their favorable physiological properties, together with current development of genetic toolboxes as presented in this review, should indicate the feasibility of these organisms as promising hosts for recombinant production in the future.

\section{Thermophilic Bacillaceae; Evolutionary Relationship and Biotechnological Potentials}

The evolutionary relationship of thermophilic Bacillus and Geobacillus strains, selected for Table 1, is shown in Figure 1. In addition to many of the favorable properties documented for B. subtilis, thermophilic Bacillaceae can in addition naturally sustain growth at elevated temperatures $\left(45-70{ }^{\circ} \mathrm{C}\right)$ and they can utilize a wide range of carbon sources for biomass and energy production $[18,19]$. One obvious advantage of looking into thermophilic Bacillaceae as hosts is exemplified in Cordova et al. where a new Geobacillus species, Geobacillus LC300, was found to grow on xylose, glucose, mannose, and galactose, with growth rates 3 times as high as that of E. coli on glucose and xylose [19]. Methylotrophic B. methanolicus grows well on both methanol and mannitol as sole carbon and energy sources at $50{ }^{\circ} \mathrm{C}[20,21]$. Furthermore, thermophilic Bacillaceae can be used for constructing DNA libraries useful in identifying genes coding for thermostable proteins as reported by Suzuki et al. (2013) and for thermoadaptation-directed evolution of very thermolabile enzymes towards increased thermostability $[22,23]$. Facultatively thermophilic B. licheniformis is widely used in industry for secretion of native enzymes, e.g., proteases, keratinase, tannase, and others; however, most of the production experiments were performed at mesophilic temperatures [4,24-29].

Several different thermophilic Bacillaceae have been thoroughly characterized in recent years, including sequencing of their genomes and transcriptomic, proteomic, and metabolomic studies 
(for details, see Table 1). For most of the industrially relevant strains, data on the high cell density cultivations is also available. For example, B. methanolicus was cultivated to final $\mathrm{OD}_{600}=13.5$ in mannitol batch fermentation and $\mathrm{OD}_{600}=53$ in methanol fed-batch fermentation, and G. thermoglucosidasius (also referred to as Parageobacillus thermoglucosidasius) reached $\mathrm{OD}_{600}$ of over 10 in batch fermentation [30,31]. A representative list of controlled fermentations and high cell density experiments using thermophilic Bacillaceae, demonstrating the feasibility of high-volume cultivations of the strains, along with information on genome sequence, transcriptome, and proteome availability is presented in Table 1.

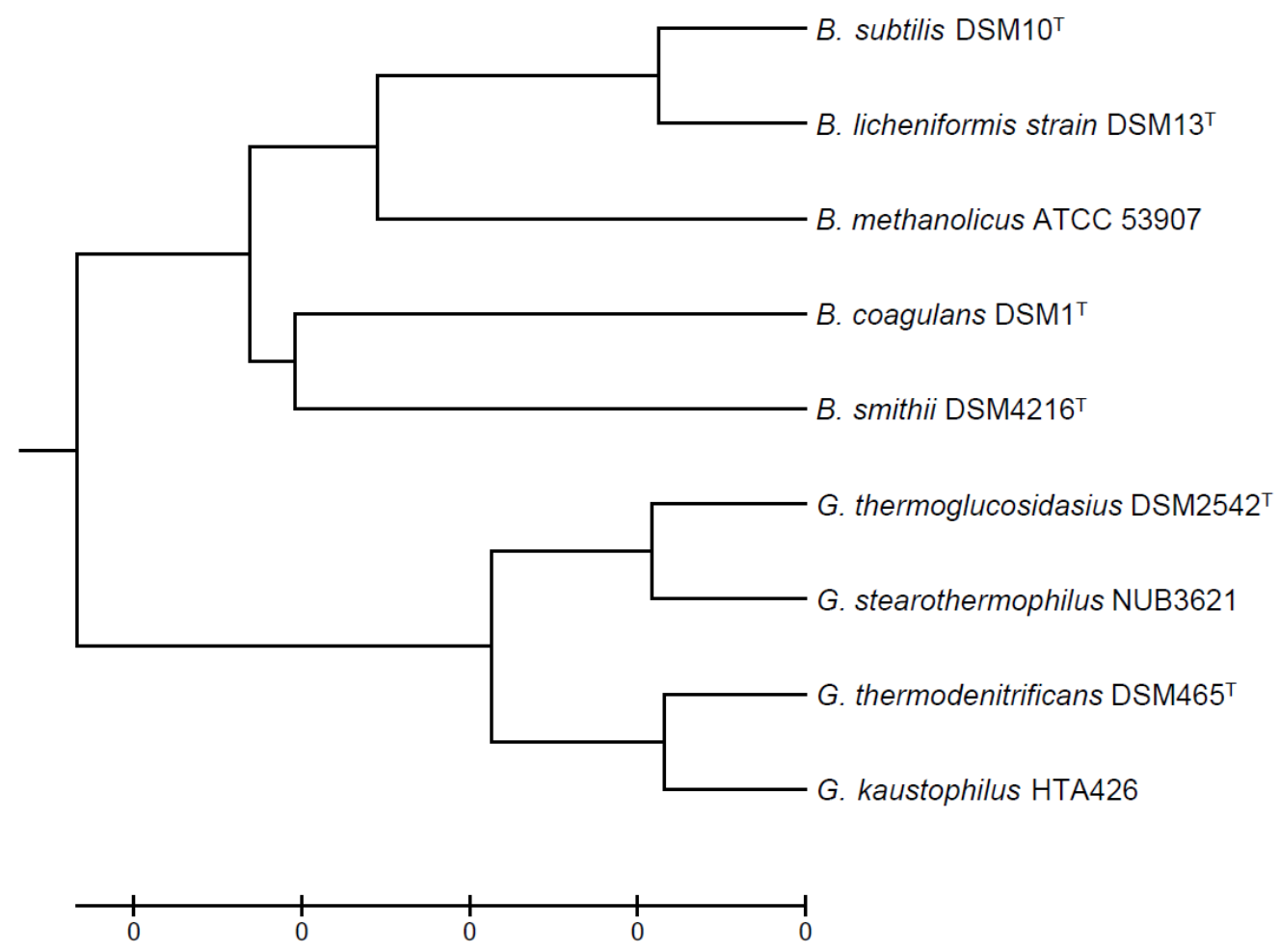

Figure 1. Evolutionary relationships of thermophilic Bacillaceae using B. subtilis as a reference strain. The evolutionary history was inferred using the UPGMA method [32]. The optimal tree with the sum of branch length $=0.22091755$ is shown. The tree is drawn to scale, with branch lengths in the same units as those of the evolutionary distances used to infer the phylogenetic tree. The evolutionary distances were computed using the Maximum Composite Likelihood method [33] and are in the units of the number of base substitutions per site. The analysis involved 9 nucleotide sequences. All positions containing gaps and missing data were eliminated. There were a total of 1387 positions in the final dataset. Evolutionary analyses were conducted in MEGA7 [34]. 
Table 1. Overview of growth temperatures, genome sequences, accession numbers, and selected high cell density cultivations for thermophilic Bacillaceae. Explanation of abbreviations: NCBI SRA: NCBI Sequence Read Archive, PX: ProteomeXchange, Uniprot ProteomID: UPID.

\begin{tabular}{|c|c|c|c|c|c|c|}
\hline Species & Strain & $\Delta \mathrm{T}\left({ }^{\circ} \mathrm{C}\right)$ & $\mathrm{T}_{\mathrm{opt}}\left({ }^{\circ} \mathrm{C}\right)$ & Sequence Data & Systems Biology Data: Accession Number (Strain) & $\begin{array}{l}\text { Controlled Fermentation Conditions } \\
\text { Main Product and Culture Volume (Strain) }\end{array}$ \\
\hline B. coagulans & $\operatorname{DSM} 1^{\mathrm{T}}[35]$ & $\mathrm{RT} / 30-55[36]$ & $40[35]$ & $\begin{array}{l}\text { ALAS00000000 (whole genome } \\
\text { shotgun sequence) [37] }\end{array}$ & $\begin{array}{l}\text { Transcriptome [38] } \\
\text { UPID: UP000031931 (DSM 1) }\end{array}$ & $\begin{array}{l}\text { L-lactic acid, } 2 \text { L (C106) [39] } \\
\text { L-lactic acid, 50 L, (DSM 23183 and DSM 23184) [40] } \\
\text { D-lactic acid, 1.2 L and } 2 \text { L (QZ19 and D-DSM 1) [41,42] }\end{array}$ \\
\hline B. smithii & DSM $4216^{\mathrm{T}}$ & $25-65[43]$ & $55[44]$ & $\begin{array}{l}\text { CP012024-CP012025 } \\
\text { (chromosome and plasmid) [44] }\end{array}$ & $\begin{array}{l}\text { UPID: UP000036353 (DSM 4216), UP000011747 } \\
\text { (7_3_47FAA) }\end{array}$ & L-lactic acid, 1 L (ET138) [18] \\
\hline B. licheniformis & $\operatorname{DSM} 13^{\mathrm{T}}$ & Up to 58 [45] & 51 [45] & $\begin{array}{l}\text { AE017333 [46] } \\
\text { CP000002 [47] }\end{array}$ & $\begin{array}{l}\text { Genome scale model: (WX-02) [48] } \\
\text { Transcriptome: } \\
\text { NCBI SRA: SRP018744 (MW3 } \triangle \text { spo, derivate of DSM } \\
\text { 13) [49] and } \\
\text { NCBI SRA: SRA482831 (DSM 13) [50] } \\
\text { Proteome: PX: PXD000791 (DSM 13) [51] } \\
\text { Metabolome [52] }\end{array}$ & $\begin{array}{l}\text { Alkaline serine protease, } 6 \mathrm{~L} \text { (MW3 } \Delta \text { spo, derivate of } \\
\text { DSM 13) [49] } \\
\text { meso-2,3-butanediol, } 40 \mathrm{~L} \text {, (MW3 } \Delta \text { gdh) [53] } \\
\text { meso-2,3-butanediol, 3 L (WX-02 } \Delta \text { gdh } \Delta a c o R) \text { [54] }\end{array}$ \\
\hline B. methanolicus & $\begin{array}{l}\text { ATCC } 53907 \\
\text { (MGA3) }\end{array}$ & $37-65[20]$ & $50-53[20]$ & $\begin{array}{l}\text { ADWW00000000 [21]; } \\
\text { CP007739, CP007740, } \\
\text { and CP007741 [55] }\end{array}$ & $\begin{array}{l}\text { Transcriptome: NCBI Gene Expression Omnibus, } \\
\text { GSE64469 [30] } \\
\text { Proteome: PX: PXD000637 } \\
\text { and PXD000638 [56] }\end{array}$ & L-glutamate, 0.75 L (ATCC 53907) [21] \\
\hline G. thermodenitrificans & DSM $465^{\mathrm{T}}$ & $45-70[57]$ & $60[58]$ & $\begin{array}{l}\text { AYKT01000001.1(DSM 465) [59] } \\
\text { CP020030-CP020032 } \\
\text { (chromosome and plasmids) } \\
\text { (T12) [60] }\end{array}$ & $\begin{array}{l}\text { Metabolome [61] } \\
\text { UPID: UP000001578 (NG80-2), UP000194134 (T12) }\end{array}$ & $\begin{array}{l}\text { L-lactic acid, } 1 \text { L (ET 144-2) [18] } \\
\text { L-lactic acid, 0.4 L (T12) [62] }\end{array}$ \\
\hline G. stearothermophilus & NUB3621 & $39-75$ [63] & 67 [63] & AOTZ01000001.1 [64] & UPID: UP000037467 (ATCC 12980) & N.D \\
\hline G. thermoglucosidasius & DSM $2542^{\mathrm{T}}$ & $40-70[67,68]$ & $61-63[68]$ & СР012712 [67] & $\begin{array}{l}\text { Genome scale model: (M10EXG) [69] and (DL33) [70] } \\
\text { Transcriptome: (DL33) [70] }\end{array}$ & $\begin{array}{l}\text { Ethanol, } 1 \text { L (NCIMB11955) [31] } \\
\text { Pectinolytic lyases, } 20 \text { L (PB94A) [71] }\end{array}$ \\
\hline
\end{tabular}




\section{Production and Secretion of Recombinant Proteins in Thermophilic Bacillaceae}

Thermophilic Bacillaceae are yet underdeveloped compared to mesophilic B. subtilis for recombinant protein production, although some examples are reported. Suzuki et al. (2013) were able to heterologously express the heterologous bgaB gene originating from $G$. stearothermophilus in G. kaustophilus HTA 426 host cells at $60^{\circ} \mathrm{C}$ [22]. Expression of the bgaB gene controlled by the native inducible promoter $\mathrm{P}_{\mathrm{gk} 704}$ from a multicopy plasmid resulted in a final yield of $28 \mathrm{mg} / \mathrm{L}$ of the purified protein product [22]. The constructed expression system was also used to recombinantly express the PH1171c protein in yields of more than $20 \mathrm{mg} / \mathrm{L}$ in G. kaustophilus [22]. In addition, the expression system was able to express soluble PH0380, a protein that is insoluble when expressed in E. coli [22]. Suziki et al. (2013) showed that the PH1171c and AmyE proteins were produced extracellularly despite lacking fused secretion signal sequences [22]. Whether this latter result was due to cell lysis or caused by an unknown secretion mechanism remained unknown [22].

One main advantage of using Gram-positive bacteria species for recombinant expression is their general high capacity for protein secretion to the extracellular space [3]. This is accomplished using orthologous secretion systems such as the general secretion pathway (Sec pathway) and the Twin-arginine translocation pathway (Tat pathway) which use different signal peptides [72,73]. The Sec pathway is able to secrete both fully and partially unfolded proteins and is the most commonly distributed secretion system in bacteria [74]. The Tat pathway on the other hand seems complementary to the Sec pathway, commonly secreting fully folded proteins that are incompatible with Sec secretion [75]. Use of these systems for production of secreted recombinant proteins were comprehensively covered in a recent review by Freudl [76].

By far the most research on protein secretion in Bacillaceae is performed in B. subtilis, and limited studies have yet been reported for thermophilic Bacillaceae. Bartosiak-Jentys et al. (2013) developed a modular system for the recombinant expression and secretion of proteins in the thermophilic G. thermoglucosidasius, and demonstrated its application to produce a secreted heterologous endoglucanase [77]. This modular system allowed a simple mode for exchange of promoter, secretion signal peptide, and the gene of interest, enabling optimization of expression level and secretion efficiency of different heterologous proteins in G. thermoglucosidasius [77]. In a separate report signal peptide sequences of $B$. subtilis and G. thermoglucosidasius were investigated and surprisingly found to be similar despite the growth temperature differences in these two organisms [78]. Signal peptides have been successfully exchanged and functionally used between $B$. licheniformis to B. subtilis, and it is thus plausible that protein secretion in thermophilic Bacillaceae can be largely achieved by adapting well-documented functional secretion systems from mesophilic bacteria [79].

\section{Plasmid Vectors and Transformation Methods}

\subsection{Plasmid Vectors}

Plasmid vectors for thermophilic Bacillaceae presented here will focus on those that have been tested at thermophilic temperatures (above $45^{\circ} \mathrm{C}$ ). The range of expression vectors available for thermophilic bacilli are based on several different origins of replication derived from different plasmids: pBC1, pUB110, pMSR0, pTA1060, pBS72 (Table 2). 
Table 2. Plasmid vectors for thermophilic bacilli.

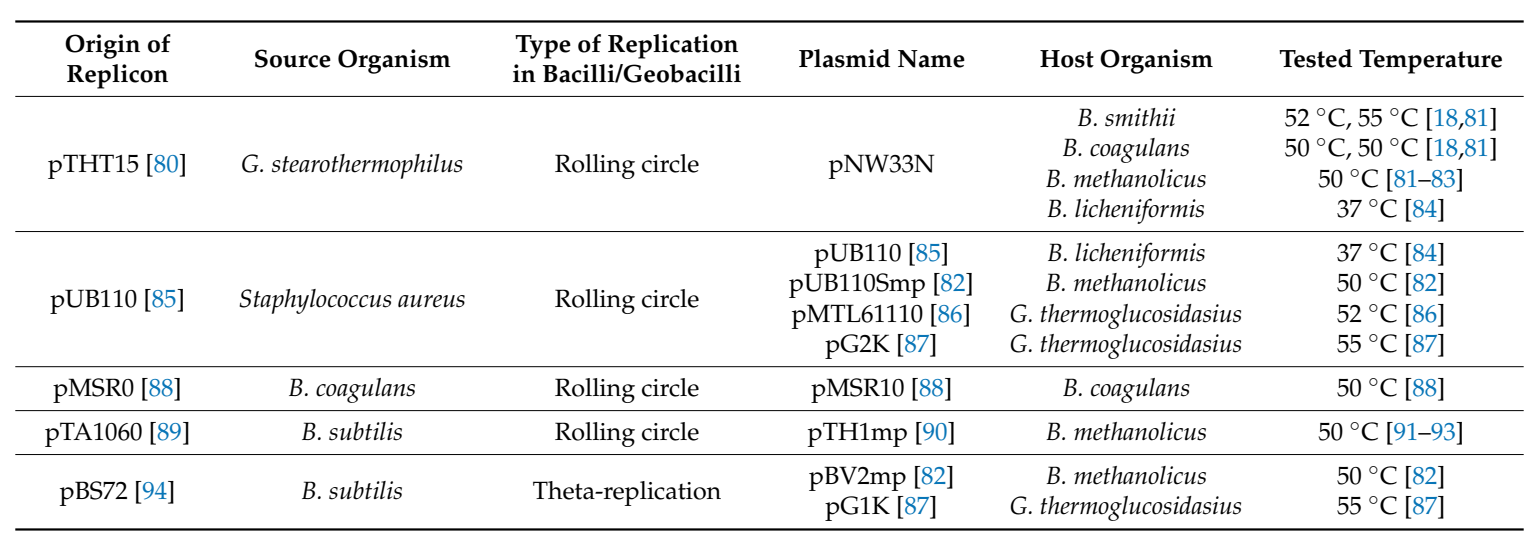

The most widely used plasmid vector for thermophilic bacilli is pNW33N. This shuttle plasmid contains a chloramphenicol acetyl transferase gene from Staphylococcus aureus plasmid pC194, an origin of replication from the E. coli plasmid pUC19, and the origin of replication for Bacillus [95]. Plasmid pNW33N has been transformed and established in several different Bacillus species, including B. smithii, B. coagulans, B. licheniformis, and B. methanolicus at temperatures above $45^{\circ} \mathrm{C}[18,81-84,88]$. Its derivative, pMU102, was shown to stably replicate in Clostridium thermocellum in temperatures up to $55^{\circ} \mathrm{C}$; temperature-sensitive variants of this plasmid were also constructed, facilitating genomic integrations in thermophilic Bacillaceae (see below) [96].

The Staphylococcus aureus-derived plasmid pUB110 was transformed and established in both B. methanolicus and B. licheniformis at $50^{\circ} \mathrm{C}$ and $37^{\circ} \mathrm{C}$, respectively, and used for production of sfGFP in B. methanolicus $[82,84,85]$. In contrast, the pUB110-derivative pDG148Stu was not transformable to $B$. coagulans $[88,97,98]$. The Bacillus/E. coli shuttle vector pMSR10 is composed of the rep region from the native B. coagulans plasmid pMSR0 and ColEI region from E. coli plasmid pUC19 and was transformed to $B$. coagulans at $50^{\circ} \mathrm{C}$ [88]. Furthermore, pTA1060-based vector pHP13 and its derivatives are routinely used for metabolic engineering of B. methanolicus at $50^{\circ} \mathrm{C}$, i.e., for recombinant expression of genes and gene clusters involved in biosynthesis of valued-added products such as the amino acids L-lysine and L-glutamate as well as platform chemicals cadaverine and $\gamma$-aminobutyric acid [91-93].

Plasmids pNW33N, pUB110, pMSR10, pHP13 all belong to the group of rolling circle plasmids, while pHCMC04 is the only theta replication plasmid that so far has been reported to be successfully transformed to any thermophilic bacilli [82,99]. It is generally assumed that theta replication plasmids are more segregationally stable than rolling circle plasmids, especially desirable for industrial fermentations that are carried out under HCDC and over many bacterial generations.

Expression vectors suitable for Geobacillus species were recently reviewed in Hussein et al. and Kananavičiūtè \& Čitavičius [100,101]. It has been shown that popular bacilli vectors pUB110 and pNW33N can also be used in geobacilli [31,102]. Furthermore, a wide range of replicons originating from different bacteria is reported to be available for geobacilli, e.g., Geobacillus-derived pBST1 (theta replication type) and pSTK1 (rolling circle replication type); Bacillus-derived pTB19 and pTHT15. A new, versatile pBST22-based system was developed with components assembled in modular combinations to create standardized plasmids. These shuttle vectors are composed of origin of replication for geobacilli, two different antibiotic resistance markers, a promoter, a repertoire of three alternative reporter genes, and ColE1 ori for E. coli [87].

None of the geobacilli-derived vectors have been reported tested in thermophilic bacilli yet. There are examples of vectors with origins of replication for bacilli that are functional in geobacilli (e.g., plasmids pNW33N and pUB110); it would therefore be interesting to test if the opposite is true as well. This would mean a substantial additional contribution in vector tools availability for thermophilic bacilli and thus facilitate establishment of heterologous gene expression and protein production in these organisms. 
A range of different replicons is available for thermophilic Bacillaceae, varying in copy number, type of replication, and stability. In the following chapters, further modules of expression vectors will be presented, i.e., antibiotics resistance markers, promoters, and reporter genes that function at elevated temperatures.

\subsection{Transformation Methods}

The availability of an effective transformation system is a prerequisite for establishing a genetic toolbox. Transformation methods reported to be in use for thermophilic Bacillaceae include protoplast transformation, natural competence, and electroporation [88,100,101]. Conjugative plasmid transfer has recently been described for thermophilic Bacillaceae, and electroporation is the most widely used transformation method for thermophilic strains in general [103]. The genetic accessibility of thermophilic bacilli seems to be species-specific and strain-specific [18,81]. Consequently, there is a need to continuously develop and improve the current transformation/electroporation protocols. It has been suggested that transformation of thermophilic bacteria might be impeded due to the low permeability of their plasma membranes [104].

\section{Promoters for Regulated and Strong Expression of Recombinant Genes}

Both constitutive and inducible promoters are generally necessary to ensure effective production of different heterologous proteins in bacterial hosts [17]. As presented in Table 3, the most commonly used inducible promoter in thermophilic bacilli is a xylose inducible promoter. In B. methanolicus, a $B$. megaterium-derived, xylose inducible promoter was demonstrated to be tightly regulated and in a dose-dependent manner [82,105]. Furthermore, this is a gratuitous promoter because B. methanolicus does not possess a xylose utilization pathway in its genome and thus there are no problems with inducer metabolism of the host. The native xylose inducible promoters were demonstrated to function well in G. thermoglucosidasius, B. smithii, and B. licheniformis [106-108]. However, all of those organisms are able to utilize xylose as a carbon source and a high basal expression from the $\mathrm{P}_{x y l A}$ promoter in G. thermoglucosidasius was observed, thus limiting its usefulness [106-108]. The mannitol inducible promoter, $\mathrm{P}_{m t l R}$, together with its synthetic variants, was applied in B. methanolicus for expression of a heterologous reporter gene, $g f p U V$; however, this promoter is not tightly regulated in B. methanolicus [82].

Table 3. Inducible promoters used in thermophilic Bacillaceae.

\begin{tabular}{ccccc}
\hline Inducer & Promoter Name & Origin of the Promoter & Host Organism & $\begin{array}{c}\text { Examples of } \\
\text { Overproduced Proteins }\end{array}$ \\
\hline xylose & $\mathrm{xpx}$ & B. megaterium [105] & B. methanolicus & GfpUV and CadA [82] \\
& $\mathrm{P}_{x y n A}$ & B. smithii [106] & B. smithii & ThermoCas9 [106] \\
& $\mathrm{P}_{x y l}$ & B. licheniformis [107] & B. licheniformis & Lichensin biosynthesis \\
& $\mathrm{P}_{x y n A}$ & G. thermoglucosidasius [108] & G. thermoglucosidasius [108] & SfGFP [108] \\
& $\mathrm{m} 2 \mathrm{p}$ & B. methanolicus [82] & B. methanolicus & GfpUV [82] \\
\hline
\end{tabular}

As far as constitutive promoters are concerned (Table 4), the methanol dehydrogenase gene $(m d h)$ promoter has been conventionally used for strong recombinant expression of many different genes in B. methanolicus strain MGA3 [91-93]. In B. coagulans, the native promoters of the pgi, $p t a$, and $l d h L$ genes encoding glucose-6-phosphate isomerase, phosphotransacetylase, and lactate dehydrogenase, respectively, were successfully tested [109]. They were used to compare the effect of a sig F deletion on central metabolism by controlling overexpression of reporter gene lacZ, coding for $\beta$-galactosidase [109]. In B. smithii, a B. coagulans-derived phosphate acetyltransferase gene ( $p t a)$ promoter was applied for expression of heterologous reporter gene and an L-lactate dehydrogenase $(l d h L)$ promoter was used for expression of the native ldhL gene [110]. The most commonly used constitutive promoter in B. licheniformis is the B. subtilis-derived p43, which so far has solely been tested 
at moderate temperatures in this organism [54,111-113]. Interestingly, the p43 promoter is apparently stronger in B. licheniformis than several of its native promoters [113]. The p43 promoter was used for production of nattokinase, which is a pharmaceutical protein, in an engineered B. licheniformis strain deprived of extracellular protease activity [114]. The nattokinase secretion efficiency was later improved by using alternative signal peptides, which is a common engineering strategy for production of extracellular proteins [114]. The B. subtilis-derived surfactin operon promoter was used for controlled recombinant expression of lichenysin biosynthesis pathway genes in B. licheniformis at moderate temperatures $[107,115]$.

Table 4. Constitutive promoters used in thermophilic bacilli.

\begin{tabular}{|c|c|c|c|}
\hline Native Gene Controlled by the Promoter & Origin of the Promoter & Host Organism & Examples of Overproduced Proteins \\
\hline$m d h$ encoding methanol dehydrohenase [91] ${ }^{*}$ & B. methanolicus & B. methanolicus [91-93] & Metabolic proteins [91-93] \\
\hline pgi encoding glucose-6-phosphate isomerase [109] & B. coagulans & B. coagulans [109] & LacZ [109] \\
\hline ldhL encoding lactate dehydrogenase [109] & B. coagulans & B. coagulans [109] & LacZ [109] \\
\hline pta encoding phosphotransacetylase [109] & B. coagulans & B. smithii $[110]$ & LacZ [109] \\
\hline ldhL encoding lactate dehydrogenase [110] & B. smithii & B. smithii [110]. & Lactate dehydrogenase [109] \\
\hline srfA operon [115] & B. subtilis & B. licheniformis & Lichenysin biosynthesis pathway [107] \\
\hline glpFK encoding glycerol utilization pathway [113] & B. licheniformis & B. licheniformis [113] & Glycerol utilization pathway [113] \\
\hline$y t z E$ encoding putative transcription factor [113] & B. licheniformis & B. licheniformis [113] & Glycerol utilization pathway [113] \\
\hline $\begin{array}{l}\text { bacABC operon coding for biosynthesis pathway of } \\
\text { the antibiotic bacilysin [113] }\end{array}$ & B. licheniformis & B. licheniformis [113] & Glycerol utilization pathway [113] \\
\hline
\end{tabular}

* Classified as constitutive promoter due to high background expression without addition of methanol and low induction window.

Transcriptome data from $B$. licheniformis has been used as a basis to identify and expand the repertoire of strong promoters for high-level expression of proteins in B. subtilis, and this strategy allowed the identification of a promoter of similar strength to the widely used p43 promoter [50]. It would be interesting to use a similar approach for identification of constitutive promoters of varying strengths based on available transcriptome data for B. licheniformis and B. methanolicus, B. coagulans and $G$. thermoglucosidasius $[30,38,49,50,70]$. Furthermore, promoter libraries were screened in G. thermoglucosidasius in order to facilitate the fine-tuning of gene expression in this bacterium, useful for both metabolic engineering and protein production $[87,108]$.

\section{Antibiotics and Selection Markers Functioning at Elevated Temperatures}

Antibiotic resistance genes are the most commonly used selection markers in microbial recombinant DNA technology, and functional thermostable selection markers are generally regarded as a bottleneck for genetic engineering in thermophilic microorganisms [116,117]. E. coli/bacilli shuttle vectors typically carry antibiotic resistance markers originating in mesophilic strains, such as chloramphenicol or kanamycin resistance genes $\left(\mathrm{Cm}^{\mathrm{r}}, \mathrm{Km}^{\mathrm{r}}\right)$ from Staphylococcus aureus [118]. A vector carrying a tetracycline resistance marker has been successfully introduced into a moderately thermophilic strain, and the spectinomycin resistance marker was shown to work with two thermophilic strains [119]. However, the typically necessary use of low antibiotic concentrations can lead to spontaneous antibiotic-resistant colonies [120,121]. Antibiotics and resistance mechanisms used under mesophilic conditions are thus not directly applicable for work with thermophilic microorganisms due to thermal instability [122]. As an example, ampicillin has a half-life of only $3.3 \mathrm{~h}$ at $72{ }^{\circ} \mathrm{C}$. However, a few antibiotics including kanamycin, neomycin, chloramphenicol, and erythromycin can be stable enough at elevated temperatures (see Table 5). Among the commonly used antibiotics in microbial molecular biology, the kanamycin molecule is reported to display the highest thermostability [122]. 
Table 5. Half-lives of selected antibiotics incubated in anaerobic medium, $72{ }^{\circ} \mathrm{C}$ and $\mathrm{pH} 7.3$ (adapted from Peteranderl et al., 1990 [122]).

\begin{tabular}{cc}
\hline Antibiotic & Half-Life $\left.\mathbf{~}_{\mathbf{1 / 2}}\right) \mathbf{( h )}$ \\
\hline Kanamycin & No detectable loss of activity \\
Neomycin & No detectable loss of activity \\
Erythromycin & 77.4 \\
Chloramphenicol & 40.6 \\
Tetracycline & 5.6 \\
Ampicillin & 3.3 \\
\hline
\end{tabular}

Mutated variants of the kanamycin resistance gene $(k n t)$ from S. aureus expressing thermostable proteins are available [123]. In G. stearothermophilus, a mutant Knt protein was shown to be catalytically functional at temperatures up to $70{ }^{\circ} \mathrm{C}$, and thermostable kanamycin resistance markers have been used in development of genetic tools in different thermophilic organisms, up to $78-80^{\circ} \mathrm{C}$ [124-126]. Directed evolution of antibiotic resistance markers of mesophilic origin resulting in isolation of thermostable mutant proteins has been reported for the antibiotics bleomycin, hygromycin, and thiostrepton [127-129].

Utilizing natural resistance mechanisms originating in thermophilic bacteria could circumvent problems with thermal stability of resistance markers. Production of antimicrobial compounds such as lantibiotics, other peptides, and bacteriocines by different thermophilic bacilli are well described [130-134]. This means that resistance mechanisms towards certain antimicrobial compounds are also then likely to exist among the thermophilic Bacillacaeae. There are, however, few reports on isolated antibiotic resistance proteins from these bacteria although production of $\beta$-lactamases for both mesophilic/thermotolerant B. licheniformis and a thermophilic Bacillus species has been reported $[135,136]$. Exploring this pool of genetic material is likely to result in more thermophile selection markers for use in engineering of thermophilic Bacillaceae. Early reports describe isolation of plasmids from thermophilic bacilli conferring tetracycline and kanamycin resistance on the transformed host $[137,138]$. The kanamycin resistance gene was later identified as the kanamycin nucleotidyltransferase gene $(k n t)$, similar to the gene on pUB110 from a mesophilic Staphylococcus aureus [139].

With the advent of metagenomics and bioprospecting of extreme environments, the discovery of new thermostable antibiotics and antibiotic resistance proteins will likely increase [140,141]. Thermophilic bacilli have been isolated from a shallow marine hot spring in Italy whereof one strain did not show sensitivity to bacitracin [142]. A thermotolerant B. licheniformis strain isolated from the same collection was later shown to produce an extracellular polysaccharide displaying antiviral activity [143]. Both findings should open for the unexhausted source of selection compounds from the thermophilic environments. Recently, two antibiotic resistance proteins from the Atlantis II Deep Red Sea brine pool $\left(68^{\circ} \mathrm{C}\right)$ were identified [144]. One of the enzymes proved to be thermostable $\left(\sim 40 \%\right.$ residual activity after $30 \mathrm{~min}$ of incubation at $\left.65^{\circ} \mathrm{C}\right)$. The gene encoded a $3^{\prime}$-aminoglycoside phosphotransferase, and its expression resulted in both kanamycin and neomycin resistance of the host cells. Summarized, these findings should represent new strategies to obtain antibiotic resistance genes for use as selectable markers in thermophiles in general and thermophilic Bacillaceae in particular.

Both due to problems associated with low thermal stability of antibiotics and as their use in industrial scale is undesirable, auxotrophic markers could be an alternative to antibiotics for plasmid selection. Auxotrophic markers are genes essential for the biosynthesis of compounds such as uracil, tryptophan, and thymidine, which the host strain is auxotrophic for, as previously reviewed [101,117]. The system utilizing auxotrophy for uracil (due to mutations in the pyrF gene) has been used for G. kaustophilus HTA426 [145].

\section{Reporter Proteins with Temperature Stability}

Reporter proteins are important for testing, developing, and improving bacterial expression systems and for thermophilic Bacillaceae it is critical to use reporters that are functionally expressed 
at the elevated temperatures. For example, the widely used green fluorescent protein (GFP) has strongly reduced fluorescence activity already at $37^{\circ} \mathrm{C}$ [146]. GFP mutant proteins have been constructed with increased thermal stability, such as super folder GFP and mutant super folder GFP, reported to have fluorescent activity in vivo at temperatures up to $70{ }^{\circ} \mathrm{C}$ in thermophilic Bacillaceae $[81,146,147]$. Additionally, Reeve et al. showed functional production of mCherry at $50{ }^{\circ} \mathrm{C}$ in G. thermoglucosidasius [87].

Recently, genes encoding novel flavin-binding proteins identified in genomes and metagenomics libraries of microorganisms isolated from Yellowstone National Park hot springs were characterized and expressed in vivo in the thermophilic bacterium Thermus thermophilus, showing activity at temperatures up to $75{ }^{\circ} \mathrm{C}$ [148]. These proteins, in addition to their stability at high temperatures, have the advantage of using flavins instead of molecular oxygen for chromophore maturation, enabling their use as reporter proteins under anaerobic conditions [148]. In addition to those thermostable reporter proteins mentioned above, the lac $Z$ gene from $B$. coagulans expressing $\beta$-galactosidase as a reporter protein has been shown to work well at elevated temperatures [109]. Another $\beta$-galactosidase isolated from G. stearothermophilus was shown to function as a thermostable reporter in G. thermoglucosidasius, resulting in black colonies on plates in the presence of the lactose analogue S-gal (3,4-cyclohexenoesculetin $\beta$-D-galactopyranoside) in temperatures between $37^{\circ} \mathrm{C}$ and $60{ }^{\circ} \mathrm{C}$ [149]. G. stearothermophilus has also been found to produce the thermostable reporter PheB, which catalyzes a reaction forming 2-hydroxymuconic semialdehyde (HMSA) [150]. This compound is reported to change the color of $G$. stearothermophilus colonies to yellow when sprayed with cathecol at $55^{\circ} \mathrm{C}$, and can alternatively be assayed spectrophotometrically in cell extracts at $375 \mathrm{~nm}$ [150].

\section{Genome Editing of Thermophilic Bacillaceae}

To develop bacterial species into valuable hosts for recombinant expression, the research focus must on the one side be on the expression systems and gene delivery methods as described thoroughly above, and on the other side also focus on optimization of the host cell itself, including removal of problematic proteases and methylases, improving secretion capacity, as well as other metabolic improvements. The latter focus relies much on access to tools and technologies enabling genome engineering in the relevant bacterial species. Establishing genome editing tools enabling stable integration of genetic elements into host chromosomes is especially important for industrial applications, where plasmid instability becomes problematic and industrial scale volumes of antibiotics for selection is unwanted. In principle, two alternative approaches can be taken to develop genome-editing tools for thermophilic Bacillaceae; one is by adapting mesophilic protocols to function at elevated temperatures and the second is to search for alternative genome editing tools from thermophilic sources. Several examples describe using homologous recombination as a method to knock out or replace chromosomal genes in thermophilic Bacillaceae. In 2012, Suzuki et al. developed a working pyrF/pyrR counterselection system for G. kaustophilus, enabling marker-free genome editing at $60{ }^{\circ} \mathrm{C}$ [145]. A similar approach was used by Kostner et al. to disrupt chromosomal alanine dehydrogenase genes in $B$. licheniformis, with the use of $\operatorname{codBA}$ as a counterselection marker at $37^{\circ} \mathrm{C}$ [151]. The pGK12 plasmid, which cannot replicate at temperatures above $42{ }^{\circ} \mathrm{C}$, was used by Wang et al. to delete the chromosomal $l d h$ and als $S$ genes in B. coagulans [41]. After cultivation of the transformed cells at $37^{\circ} \mathrm{C}$, which is permissive for plasmid replication, a temperature shift to $50{ }^{\circ} \mathrm{C}$ caused selection for deletion mutants where the plasmid had integrated into the target chromosomal site [41]. The initial cultivation step at temperatures permissive to plasmid replication was critical, as it countered the low transformation efficiency of B. coagulans [41]. Cripps et al. used the plasmid pTMO19, a derivative of the thermosensitive pNW33N, to knock out the chromosomal ldh and pflB genes in G. thermoglucosidasius by using a similar strategy [31]. Bosma et al. demonstrated the use of the pNW33N plasmid to knock out the ldhL gene in B. smithii ET 138 through homologous recombination, similar to Wang et al. and Cripps et al. [110]. A counterselection marker, lacZ, was included on the plasmid to allow for a second crossover event and the generation of a scarless 
knockout mutant [110]. Interestingly, the authors reported that plasmid integration occurred without a temperature increase, which could hint at a highly efficient recombination machinery in B. smithii ET 138 [110]. After successful chromosomal integration was observed, the insert could be forced out in a second crossover event by applying counterselection pressure through addition of 5-bromo-4-chloro-3-indolyl- $\beta$-D-galactopyranoside (X-gal) to the medium, resulting in a scarless knockout mutant [110]. Kovacs et al. (2010) used the Cre-lox system to create knock out mutants in B. coagulans at elevated temperatures $\left(45^{\circ} \mathrm{C}\right)$ [109]. After chromosomal integration of a thermosensitive plasmid with selection markers, similar to the above-mentioned strategies, a second thermosensitive plasmid containing the Cre-lox system was transformed into the knockout mutants [109]. Cre then recombined the lox66 and lox71 sites flanking the cat selection marker on the integrated plasmid into a lox72 site [109]. This removed the integrated plasmid, leaving behind only the lox72 site which is not recognized by Cre [109]. The Cre-lox system could be useful in other thermophilic Bacillaceae species for establishing knockout mutants, but the requirement for functional Cre protein expression could prove challenging in other species and the scar left behind in the form of the lox72 site limits the applications of this method. An alternative approach to using thermosensitive replicons in order to force chromosomal integration of selection markers is the use of bacterial conjugation to transfer plasmids unable to replicate in the recipient cell. In order to avoid succumbing to selection pressure, the recipient cell must integrate a selection marker flanked by homology regions into its chromosome, rendering it resistant to the selection agent. Conjugation between E. coli and thermophilic geobacilli was previously covered in a review by Kananavičiūtè and Čitavičius, and conjugation of a pUB110-based plasmid from E. coli into B. licheniformis was performed by Hertel et al. [101,152].

The success of the CRISPR/Cas9 system for genome editing in both prokaryotes and eukaryotes has enabled an accelerated pace in strain engineering. The most common Cas9 variant, spCas9, derived from the mesophilic bacterium Streptococcus pyogenes was reported to lose its catalytic activity at $42{ }^{\circ} \mathrm{C}[126,153]$. This limits the usability of spCas9 in thermophilic Bacillaceae, but temporary cultivation temperature shifts to permissive temperatures (below $42{ }^{\circ} \mathrm{C}$ ) have been shown to allow genomic modifications [126]. Mougiakos et al. demonstrated genome editing of $B$. smithii using spCas 9 at $37{ }^{\circ} \mathrm{C}$ combined with homologous recombination templates [126]. Another example of genome editing by spCas9 in facultatively thermophilic bacilli was achieved by Li et al., when an spCas9 nickase mutant gene combined with homologous recombination templates was used to produce single- and multi-knock-out strains of B. licheniformis with high efficiencies [154]. While the strategy of lowering the growth temperature to the permissive one to allow proper enzyme function has proven to be successful, this strategy is not feasible for species that do not grow or survive in spCas 9 permissive temperatures. Finding thermostable alternatives to spCas9 is therefore important for the development of a robust genome editing toolbox for thermophilic bacilli.

In 2017, Mougiakos et al. successfully applied a novel Cas9 enzyme isolated from G. thermodenitrificans to genetically engineer B. smithii [106]. This Cas9 variant was shown to retain catalytic activity in the temperature range between $20^{\circ} \mathrm{C}$ and $70{ }^{\circ} \mathrm{C}$, and with its lenient PAM sequence, this Cas9 variant should be a promising candidate for genome editing in thermophilic organisms [106].

\section{Concluding Remarks}

Thermophilic Bacillaceae typically have their growth optima around $50{ }^{\circ} \mathrm{C}$, which on the one hand can offer process advantages with respect to thermostable protein folding and functionality, and on the other hand can present challenges with respect to availability of functional genetic tools. Today's progress in research and development on strains belonging to this group should open for their potential use as alternative hosts for recombinant protein production at elevated temperatures. In particular, there is extensive research going on in development of genetic tools and recombinant technologies, as reviewed here, that eventually should pave the way for the use of this group of bacteria as alternative and attractive hosts for heterologous protein production. In addition, systems biology investigations to increase our understanding of their genetics and physiology, together with 
establishment of functional genome-editing methodologies, should open for rational improvement of strains useful hosts for recombinant expression of both proteins and biosynthetic pathways for industrial biotechnology purposes.

Acknowledgments: This work was supported by grants from the Research Council of Norway under the Center for Digital Life Norway and the ERA_MBT project ThermoFactories.

Conflicts of Interest: The authors declare no conflict of interest.

\section{References}

1. Zhou, Y.; Lu, Z.; Wang, X.; Selvaraj, J.N.; Zhang, G. Genetic engineering modification and fermentation optimization for extracellular production of recombinant proteins using Escherichia coli. Appl. Microbiol. Biotechnol. 2018, 102, 1545-1556. [CrossRef] [PubMed]

2. Song, Y.; Nikoloff, J.M.; Zhang, D. Improving Protein Production on the Level of Regulation of both Expression and Secretion Pathways in Bacillus subtilis. J. Microbiol. Biotechnol. 2015, 25, 963-977. [CrossRef] [PubMed]

3. Marjo Simonen, I.P. Protein Secretion in Bacillus Species. Microbiol. Rev. 1993, 57, 109-137.

4. Schallmey, M.; Singh, A.; Ward, O.P. Developments in the use of Bacillus species for industrial production. Can. J. Microbiol. 2004, 50, 1-17. [CrossRef] [PubMed]

5. Pohl, S.; Bhavsar, G.; Hulme, J.; Bloor, A.E.; Misirli, G.; Leckenby, M.W.; Radford, D.S.; Smith, W.; Wipat, A.; Williamson, E.D.; et al. Proteomic analysis of Bacillus subtilis strains engineered for improved production of heterologous proteins. Proteomics 2013, 13, 3298-3308. [CrossRef] [PubMed]

6. Cao, H.; van Heel, A.J.; Ahmed, H.; Mols, M.; Kuipers, O.P. Cell surface engineering of Bacillus subtilis improves production yields of heterologously expressed alpha-amylases. Microb. Cell Fact. 2017, 16, 56. [CrossRef] [PubMed]

7. Morimoto, T.; Kadoya, R.; Endo, K.; Tohata, M.; Sawada, K.; Liu, S.; Ozawa, T.; Kodama, T.; Kakeshita, H.; Kageyama, Y.; et al. Enhanced recombinant protein productivity by genome reduction in Bacillus subtilis. DNA Res. 2008, 15, 73-81. [CrossRef] [PubMed]

8. Van Dijl, J.; Hecker, M. Bacillus subtilis: From soil bacterium to super-secreting cell factory. Microb. Cell Fact. 2013, 12. [CrossRef] [PubMed]

9. Lakowitz, A.; Godard, T.; Biedendieck, R.; Krull, R. Mini review: Recombinant production of tailored bio-pharmaceuticals in different Bacillus strains and future perspectives. Eur. J. Pharm. Biopharm. 2017, 126, 27-39. [CrossRef] [PubMed]

10. Sarvas, M.; Harwood, C.R.; Bron, S.; van Dijl, J.M. Post-translocational folding of secretory proteins in Gram-positive bacteria. Biochim. Biophys. Acta 2004, 1694, 311-327. [CrossRef] [PubMed]

11. Nazina, T.N.; Tourova, T.P.; Poltaraus, A.B.; Novikova, E.V.; Grigoryan, A.A.; Ivanova, A.E.; Lysenko, A.M.; Petrunyaka, V.V.; Osipov, G.A.; Belyaev, S.S.; et al. Taxonomic study of aerobic thermophilic bacilli: Descriptions of Geobacillus subterraneus gen. nov., sp. nov. and Geobacillus uzenensis sp. nov. from petroleum reservoirs and transfer of Bacillus stearothermophilus, Bacillus thermocatenulatus, Bacillus thermoleovorans, Bacillus kaustophilus, Bacillus thermodenitrificans to Geobacillus as the new combinations G. stearothermophilus, G. thermocatenulatus, G. thermoleovorans, G. kaustophilus, G. thermoglucosidasius and G. thermodenitrificans. Int. J. Syst. Evol. Microbiol. 2001, 51, 433-446. [PubMed]

12. Bausum, H.T.; Matney, T.S. Boundary between Bacterial Mesophilism and Thermophilism. J. Bacteriol. 1965, 90, 50-53. [PubMed]

13. Donati, E.R.; Castro, C.; Urbieta, M.S. Thermophilic microorganisms in biomining. World J. Microbiol. Biotechnol. 2016, 32, 179. [CrossRef] [PubMed]

14. De Clerck, E.; Rodriguez-Diaz, M.; Forsyth, G.; Lebbe, L.; Logan, N.A.; DeVos, P. Polyphasic Characterization of Bacillus coagulans Strains, Illustrating Heterogeneity within this Species, and Emended Description of the Species. Syst. Appl. Microbiol. 2004, 27, 50-60. [CrossRef] [PubMed]

15. Patel, M.A.; Ou, M.S.; Harbrucker, R.; Aldrich, H.C.; Buszko, M.L.; Ingram, L.O.; Shanmugam, K.T. Isolation and characterization of acid-tolerant, thermophilic bacteria for effective fermentation of biomass-derived sugars to lactic acid. Appl. Environ. Microbiol. 2006, 72, 3228-3235. [CrossRef] [PubMed] 
16. Ou, M.S.; Mohammed, N.; Ingram, L.O.; Shanmugam, K.T. Thermophilic Bacillus coagulans requires less cellulases for simultaneous saccharification and fermentation of cellulose to products than mesophilic microbial biocatalysts. Appl. Biochem. Biotechnol. 2009, 155, 379-385. [CrossRef] [PubMed]

17. Boyle, P.M.; Silver, P.A. Parts plus pipes: Synthetic biology approaches to metabolic engineering. Metab. Eng. 2012, 14, 223-232. [CrossRef] [PubMed]

18. Bosma, E.F.; van de Weijer, A.H.; Daas, M.J.; van der Oost, J.; de Vos, W.M.; van Kranenburg, R. Isolation and screening of thermophilic bacilli from compost for electrotransformation and fermentation: Characterization of Bacillus smithii ET 138 as a new biocatalyst. Appl. Environ. Microbiol. 2015, 81, 1874-1883. [CrossRef] [PubMed]

19. Cordova, L.T.; Long, C.P.; Venkataramanan, K.P.; Antoniewicz, M.R. Complete genome sequence, metabolic model construction and phenotypic characterization of Geobacillus LC300, an extremely thermophilic, fast growing, xylose-utilizing bacterium. Metab. Eng. 2015, 32, 74-81. [CrossRef] [PubMed]

20. Schendel, F.J.; Bremmon, C.E.; Flickinger, M.C.; Guettler, M.; Hanson, R.S. L-lysine production at $50 \mathrm{C}$ by mutants of a newly isolated and characterized methylotrophic Bacillus sp. Appl. Environ. Microbiol. 1990, 56, 963-970. [PubMed]

21. Heggeset, T.M.; Krog, A.; Balzer, S.; Wentzel, A.; Ellingsen, T.E.; Brautaset, T. Genome sequence of thermotolerant Bacillus methanolicus: Features and regulation related to methylotrophy and production of L-lysine and L-glutamate from methanol. Appl. Environ. Microbiol. 2012, 78, 5170-5181. [CrossRef] [PubMed]

22. Suzuki, H.; Yoshida, K.; Ohshima, T. Polysaccharide-degrading thermophiles generated by heterologous gene expression in Geobacillus kaustophilus HTA426. Appl. Environ. Microbiol. 2013, 79, 5151-5158. [CrossRef] [PubMed]

23. Suzuki, H.; Kobayashi, J.; Wada, K.; Furukawa, M.; Doi, K. Thermoadaptation-directed enzyme evolution in an error-prone thermophile derived from Geobacillus kaustophilus HTA426. Appl. Environ. Microbiol. 2015, 81, 149-158. [CrossRef] [PubMed]

24. Sarker, P.K.; Talukdar, S.A.; Deb, P.; Sayem, S.M.A.; Mohsina, K. Optimization and partial characterization of culture conditions for the production of alkaline protease from Bacillus licheniformis P003. SpringerPlus 2013, 2, 506. [CrossRef] [PubMed]

25. Drouin, M.; Lai, C.K.; Tyagi, R.D.; Surampalli, R.Y. Bacillus licheniformis proteases as high value added products from fermentation of wastewater sludge: Pre-treatment of sludge to increase the performance of the process. Water Sci. Technol. 2008, 57, 423-429. [CrossRef] [PubMed]

26. Fakhfakh, N.; Kanoun, S.; Manni, L.; Nasri, M. Production and biochemical and molecular characterization of a keratinolytic serine protease from chicken feather-degrading Bacillus licheniformis RPk. Can. J. Microbiol. 2009, 55, 427-436. [CrossRef] [PubMed]

27. Ni, H.; Chen, Q.-H.; Chen, F.; Fu, M.-L.; Dong, Y.-C.; Cai, H.-N. Improved keratinase production for feather degradation by Bacillus licheniformis ZJUEL31410 in submerged cultivation. Afr. J. Biotechnol. 2011, 10, 7236-7244.

28. Das Mohapatra, P.K.; Maity, C.; Rao, R.S.; Pati, B.R.; Mondal, K.C. Tannase production by Bacillus licheniformis KBR6: Optimization of submerged culture conditions by Taguchi DOE methodology. Food Res. Int. 2009, 42, 430-435. [CrossRef]

29. Parrado, J.; Rodriguez-Morgado, B.; Tejada, M.; Hernandez, T.; Garcia, C. Proteomic analysis of enzyme production by Bacillus licheniformis using different feather wastes as the sole fermentation media. Enzyme Microb. Technol. 2014, 57, 1-7. [CrossRef] [PubMed]

30. Irla, M.; Neshat, A.; Brautaset, T.; Ruckert, C.; Kalinowski, J.; Wendisch, V.F. Transcriptome analysis of thermophilic methylotrophic Bacillus methanolicus MGA3 using RNA-sequencing provides detailed insights into its previously uncharted transcriptional landscape. BMC Genom. 2015, 16, 73. [CrossRef] [PubMed]

31. Cripps, R.E.; Eley, K.; Leak, D.J.; Rudd, B.; Taylor, M.; Todd, M.; Boakes, S.; Martin, S.; Atkinson, T. Metabolic engineering of Geobacillus thermoglucosidasius for high yield ethanol production. Metab. Eng. 2009, 11, 398-408. [CrossRef] [PubMed]

32. Sneath, P.H.A.; Sokal, R.R. Numerical Taxonomy; Freeman: San Francisco, CA, USA, 1973.

33. Tamura, K.; Nei, M.; Kumar, S. Prospects for inferring very large phylogenies by using the neighbor-joining method. Proc. Natl. Acad. Sci. USA 2004, 101, 11030-11035. [CrossRef] [PubMed]

34. Kumar, S.; Stecher, G.; Tamura, K. MEGA7: Molecular Evolutionary Genetics Analysis Version 7.0 for Bigger Datasets. Mol. Biol. Evol. 2016, 33, 1870-1874. [CrossRef] [PubMed] 
35. Bacillus coagulans Hammer 1915 emend. De Clerck et al. 2004. Available online: https://www.dsmz.de/ catalogues/details/culture/dsm-1.html (accessed on 30 April 2018).

36. Hammer, B.W. Bacteriological studies on the coagulation of evaporated milk. Agric. Res. Bull. 1915, 119-131.

37. Su, F.; Tao, F.; Tang, H.; Xu, P. Genome sequence of the thermophile Bacillus coagulans Hammer, the type strain of the species. J. Bacteriol. 2012, 194, 6294-6295. [CrossRef] [PubMed]

38. Wang, X.; Qin, J.; Zhu, Q.; Zhu, B.; Zhang, X.; Yao, Q. Transcriptome analysis of Bacillus coagulans P38, an efficient producer of L-lactic acid from cellulosic hydrolysate, in response to 2-furfural stress. Ann. Microbiol. 2016, 66, 889-894. [CrossRef]

39. Ye, L.; Zhou, X.; Hudari, M.S.; Li, Z.; Wu, J.C. Highly efficient production of L-lactic acid from xylose by newly isolated Bacillus coagulans C106. Bioresour. Technol. 2013, 132, 38-44. [CrossRef] [PubMed]

40. Xu, P.; Wang, L.; Zhao, B.; Ma, C.; Su, F.; Tao, F.; Tang, H. Bacillus coagulans Strains and Their Applications in L-Lactic Acid Production. U.S. Patent No. 8,492,127, 23 July 2013.

41. Wang, Q.; Ingram, L.O.; Shanmugam, K.T. Evolution of D-lactate dehydrogenase activity from glycerol dehydrogenase and its utility for D-lactate production from lignocellulose. Proc. Natl. Acad. Sci. USA 2011, 108, 18920-18925. [CrossRef] [PubMed]

42. Zhang, C.; Zhou, C.; Assavasirijinda, N.; Yu, B.; Wang, L.; Ma, Y. Non-sterilized fermentation of high optically pure D-lactic acid by a genetically modified thermophilic Bacillus coagulans strain. Microb. Cell Fact. 2017, 16, 213. [CrossRef] [PubMed]

43. Nakamura, L.K.; Blumenstock, I.; Claus, D. Taxonomic Study of Bacillus coagulans Hammer 1915 with a Proposal for Bacillus smithii sp. nov. Int. J. Syst. Evol. Microbiol. 1988, 38, 63-73. [CrossRef]

44. Bosma, E.F.; Koehorst, J.J.; van Hijum, S.A.; Renckens, B.; Vriesendorp, B.; van de Weijer, A.H.; Schaap, P.J.; de Vos, W.M.; van der Oost, J.; van Kranenburg, R. Complete genome sequence of thermophilic Bacillus smithii type strain DSM 4216(T). Stand. Genom. Sci. 2016, 11, 52. [CrossRef] [PubMed]

45. Warth, A.D. Relationship between the heat resistance of spores and the optimum and maximum growth temperatures of Bacillus species. J. Bacterol. 1978, 134, 699-705.

46. Veith, B.; Herzberg, C.; Steckel, S.; Feesche, J.; Maurer, K.H.; Ehrenreich, P.; Baumer, S.; Henne, A.; Liesegang, H.; Merkl, R.; et al. The complete genome sequence of Bacillus licheniformis DSM13, an organism with great industrial potential. J. Mol. Microbiol. Biotechnol. 2004, 7, 204-211. [CrossRef] [PubMed]

47. Rey, M.W.; Ramaiya, P.; Nelson, B.A.; Brody-Karpin, S.D.; Zaretsky, E.J.; Tang, M.; Lopez de Leon, A.; Xiang, H.; Gusti, V.; Groth Clausen, I.; et al. Complete genome sequence of the industrial bacterium Bacillus licheniformis and comparisons with closely related Bacillus species. Genome Biol. 2004, 5, R77. [CrossRef] [PubMed]

48. Guo, J.; Zhang, H.; Wang, C.; Chang, J.W.; Chen, L.L. Construction and analysis of a genome-scale metabolic network for Bacillus licheniformis WX-02. Res. Microbiol. 2016, 167, 282-289. [CrossRef] [PubMed]

49. Wiegand, S.; Dietrich, S.; Hertel, R.; Bongaerts, J.; Evers, S.; Volland, S.; Daniel, R.; Liesegang, H. RNA-Seq of Bacillus licheniformis: Active regulatory RNA features expressed within a productive fermentation. BMC Genom. 2013, 14, 667. [CrossRef] [PubMed]

50. Liu, X.; Yang, H.; Zheng, J.; Ye, Y.; Pan, L. Identification of strong promoters based on the transcriptome of Bacillus licheniformis. Biotechnol. Lett. 2017, 39, 873-881. [CrossRef] [PubMed]

51. Voigt, B.; Albrecht, D.; Sievers, S.; Becher, D.; Bongaerts, J.; Evers, S.; Schweder, T.; Maurer, K.H.; Hecker, M. High-resolution proteome maps of Bacillus licheniformis cells growing in minimal medium. Proteomics 2015, 15, 2629-2633. [CrossRef] [PubMed]

52. Wang, H.; Chen, Z.; Yang, J.; Liu, Y.; Lu, F. Optimization of sample preparation for the metabolomics of Bacillus licheniformis by GC-MS. In Advances in Applied Biotechnology; Springer: Berlin/Heidelberg, Germany, 2015; pp. 579-588.

53. Ge, Y.; Li, K.; Li, L.; Gao, C.; Zhang, L.; Ma, C.; Xu, P. Contracted but effective: Production of enantiopure 2,3-butanediol by thermophilic and GRAS Bacillus licheniformis. Green Chem. 2016, 18, 4693-4703. [CrossRef]

54. Qiu, Y.; Zhang, J.; Li, L.; Wen, Z.; Nomura, C.T.; Wu, S.; Chen, S. Engineering Bacillus licheniformis for the production of meso 2,3 butanediol. Biotechnol. Biofuels 2016, 9, 117. [CrossRef] [PubMed]

55. Irla, M.; Neshat, A.; Winkler, A.; Albersmeier, A.; Heggeset, T.M.; Brautaset, T.; Kalinowski, J.; Wendisch, V.F.; Ruckert, C. Complete genome sequence of Bacillus methanolicus MGA3, a thermotolerant amino acid producing methylotroph. J. Biotechnol. 2014, 188, 110-111. [CrossRef] [PubMed] 
56. Muller, J.E.; Litsanov, B.; Bortfeld-Miller, M.; Trachsel, C.; Grossmann, J.; Brautaset, T.; Vorholt, J.A. Proteomic analysis of the thermophilic methylotroph Bacillus methanolicus MGA3. Proteomics 2014, 14, 725-737. [CrossRef] [PubMed]

57. Manachini, P.L.; Mora, D.; Nicastro, G.; Parini, C.; Stackebrandt, E.; Pukall, R.; Fortina, M.G. Bacillus thermodenitrificans sp. nov., nom. rev. Int. J. Syst. Evol. Microbiol. 2000, 50, 1331-1337. [CrossRef] [PubMed]

58. Cihan, A.C.; Ozcan, B.; Tekin, N.; Cokmus, C. Geobacillus thermodenitrificans subsp. calidus, subsp. nov., a thermophilic and alpha-glucosidase producing bacterium isolated from Kizilcahamam, Turkey. J. Gen. Appl. Microbiol. 2011, 57, 83-92. [PubMed]

59. Yao, N.; Ren, Y.; Wang, W. Genome Sequence of a Thermophilic Bacillus, Geobacillus thermodenitrificans DSM465. Genome Announc. 2013, 1. [CrossRef] [PubMed]

60. Daas, M.J.A.; Vriesendorp, B.; van de Weijer, A.H.P.; van der Oost, J.; van Kranenburg, R. Complete Genome Sequence of Geobacillus thermodenitrificans T12, A Potential Host for Biotechnological Applications. Curr. Microbiol. 2018, 75, 49-56. [CrossRef] [PubMed]

61. Carnicer, M.; Vieira, G.; Brautaset, T.; Portais, J.C.; Heux, S. Quantitative metabolomics of the thermophilic methylotroph Bacillus methanolicus. Microb. Cell Fact. 2016, 15, 92. [CrossRef] [PubMed]

62. Daas, M.J.; van de Weijer, A.H.; de Vos, W.M.; van der Oost, J.; van Kranenburg, R. Isolation of a genetically accessible thermophilic xylan degrading bacterium from compost. Biotechnol. Biofuels 2016, 9, 210. [CrossRef] [PubMed]

63. Wu, L.; Welker, N.E. Temperature-induced protein synthesis in Bacillus stearothermophilus NUB36. J. Bacteriol. 1991, 173, 4889-4892. [CrossRef] [PubMed]

64. Blanchard, K.; Robic, S.; Matsumura, I. Transformable facultative thermophile Geobacillus stearothermophilus NUB3621 as a host strain for metabolic engineering. Appl. Microbiol. Biotechnol. 2014, 98, 6715-6723. [CrossRef] [PubMed]

65. Takami, H.; Takaki, Y.; Chee, G.J.; Nishi, S.; Shimamura, S.; Suzuki, H.; Matsui, S.; Uchiyama, I. Thermoadaptation trait revealed by the genome sequence of thermophilic Geobacillus kaustophilus. Nucleic Acids Res. 2004, 32, 6292-6303. [CrossRef] [PubMed]

66. Lee, D.W.; Kim, D.; Lee, Y.J.; Kim, J.A.; Choi, J.Y.; Kang, S.; Pan, J.G. Proteomic analysis of acetylation in thermophilic Geobacillus kaustophilus. Proteomics 2013, 13, 2278-2282. [CrossRef] [PubMed]

67. Chen, J.; Zhang, Z.; Zhang, C.; Yu, B. Genome sequence of Geobacillus thermoglucosidasius DSM2542, a platform hosts for biotechnological applications with industrial potential. J. Biotechnol. 2015, 216, 98-99. [CrossRef] [PubMed]

68. Suzuki, Y.; Kishigami, T.; Inoue, K.; Mizoguchi, Y.; Eto, N.; Takagi, M.; Abe, S. Bacillus thermoglucosidasius sp. nov., a new species of obligately thermophilic bacilli. Syst. Appl. Microbiol. 1983, 4, 487-495. [CrossRef]

69. Tang, Y.J.; Sapra, R.; Joyner, D.; Hazen, T.C.; Myers, S.; Reichmuth, D.; Blanch, H.; Keasling, J.D. Analysis of metabolic pathways and fluxes in a newly discovered thermophilic and ethanol-tolerant Geobacillus strain. Biotechnol. Bioeng. 2009, 102, 1377-1386. [CrossRef] [PubMed]

70. Ward, C.E. Application of Metabolic Flux and Transcriptome Analyses to Understanding the Physiology of Engineered Geobacillus thermoglucosidasius; Imperial College London: London, UK, 2014.

71. Valladares Juarez, A.G.; Dreyer, J.; Gopel, P.K.; Koschke, N.; Frank, D.; Markl, H.; Muller, R. Characterisation of a new thermoalkaliphilic bacterium for the production of high-quality hemp fibres, Geobacillus thermoglucosidasius strain PB94A. Appl. Microbiol. Biotechnol. 2009, 83, 521-527. [CrossRef] [PubMed]

72. Yamane, K.; Bunai, K.; Kakeshita, H. Protein Traffic for Secretion and Related Machinery of Bacillus subtilis. Biosci. Biotechnol. Biochem. 2004, 68, 2007-2023. [CrossRef] [PubMed]

73. Jongbloed, J.D.; Antelmann, H.; Hecker, M.; Nijland, R.; Bron, S.; Airaksinen, U.; Pries, F.; Quax, W.J.; van Dijl, J.M.; Braun, P.G. Selective contribution of the twin-arginine translocation pathway to protein secretion in Bacillus subtilis. J. Biol. Chem. 2002, 277, 44068-44078. [CrossRef] [PubMed]

74. De Keyzer, J.; van der Does, C.; Driessen, A.J. The bacterial translocase: A dynamic protein channel complex. Cell. Mol. Life Sci. 2003, 60, 2034-2052. [CrossRef] [PubMed]

75. Natale, P.; Bruser, T.; Driessen, A.J. Sec- and Tat-mediated protein secretion across the bacterial cytoplasmic membrane-Distinct translocases and mechanisms. Biochim. Biophys. Acta 2008, 1778, 1735-1756. [CrossRef] [PubMed]

76. Freudl, R. Signal peptides for recombinant protein secretion in bacterial expression systems. Microb. Cell Fact. 2018, 17, 52. [CrossRef] [PubMed] 
77. Bartosiak-Jentys, J.; Hussein, A.H.; Lewis, C.J.; Leak, D.J. Modular system for assessment of glycosyl hydrolase secretion in Geobacillus thermoglucosidasius. Microbiology 2013, 159, 1267-1275. [CrossRef] [PubMed]

78. Holland, A. Optimisation of Feedstock Utilisation by Geobacillus thermoglucosidasius. Ph.D Thesis, University of Bath, Bath, UK, 2017.

79. Degering, C.; Eggert, T.; Puls, M.; Bongaerts, J.; Evers, S.; Maurer, K.H.; Jaeger, K.E. Optimization of protease secretion in Bacillus subtilis and Bacillus licheniformis by screening of homologous and heterologous signal peptides. Appl. Environ. Microbiol. 2010, 76, 6370-6376. [CrossRef] [PubMed]

80. De Rossi, E.; Milano, A.; Brigidi, P.; Bini, F.; Riccardi, G. Structural organization of pBC1, a cryptic plasmid from Bacillus coagulans. J. Bacteriol. 1992, 174, 638-642. [CrossRef] [PubMed]

81. Frenzel, E.; Legebeke, J.; van Stralen, A.; van Kranenburg, R.; Kuipers, O.P. In vivo selection of sfGFP variants with improved and reliable functionality in industrially important thermophilic bacteria. Biotechnol. Biofuels 2018, 11. [CrossRef] [PubMed]

82. Irla, M.; Heggeset, T.M.; Naerdal, I.; Paul, L.; Haugen, T.; Le, S.B.; Brautaset, T.; Wendisch, V.F. Genome-Based Genetic Tool Development for Bacillus methanolicus: Theta- and Rolling Circle-Replicating Plasmids for Inducible Gene Expression and Application to Methanol-Based Cadaverine Production. Front. Microbiol. 2016, 7, 1481. [CrossRef] [PubMed]

83. Nilasari, D.; Dover, N.; Rech, S.; Komives, C. Expression of Recombinant Green Fluorescent Protein in Bacillus methanolicus. Biotechnol. Prog. 2012, 28, 662-668. [CrossRef] [PubMed]

84. Wang, Q.; Chen, T.; Zhao, X.; Chamu, J. Metabolic engineering of thermophilic Bacillus licheniformis for chiral pure D-2,3-butanediol production. Biotechnol. Bioeng. 2012, 109, 1610-1621. [CrossRef] [PubMed]

85. Gryczan, T.J.; Contente, S.; Dubnau, D. Characterization of Staphylococcus aureus plasmids introduced by transformation into Bacillus subtilis. J. Bacteriol. 1978, 134, 318-329. [PubMed]

86. Sheng, L.; Kovacs, K.; Winzer, K.; Zhang, Y.; Minton, N.P. Development and implementation of rapid metabolic engineering tools for chemical and fuel production in Geobacillus thermoglucosidasius NCIMB 11955. Biotechnol. Biofuels 2017, 10, 5. [CrossRef] [PubMed]

87. Reeve, B.; Martinez-Klimova, E.; de Jonghe, J.; Leak, D.J.; Ellis, T. The Geobacillus Plasmid Set: A Modular Toolkit for Thermophile Engineering. ACS Synth. Biol. 2016, 5, 1342-1347. [CrossRef] [PubMed]

88. Rhee, M.S.; Kim, J.-W.; Qian, Y.; Ingram, L.O.; Shanmugam, K.T. Development of plasmid vector and electroporation condition for gene transfer in sporogenic lactic acid bacterium, Bacillus coagulans. Plasmid 2007, 58, 13-22. [CrossRef] [PubMed]

89. Uozumi, T.; Ozaki, A.; Beppu, T.; Arima, K. New cryptic plasmid of Bacillus subtilis and restriction analysis of other plasmids found by general screening. J. Bacteriol. 1980, 142, 315-318. [PubMed]

90. Brautaset, T.; Jakobsen, O.M.; Degnes, K.F.; Netzer, R.; Naerdal, I.; Krog, A.; Dillingham, R.; Flickinger, M.C.; Ellingsen, T.E. Bacillus methanolicus pyruvate carboxylase and homoserine dehydrogenase I and II and their roles for L-lysine production from methanol at $50^{\circ} \mathrm{C}$. Appl. Microbiol. Biotechnol. 2010, 87, 951-964. [CrossRef] [PubMed]

91. Jakobsen, O.M.; Brautaset, T.; Degnes, K.F.; Heggeset, T.M.; Balzer, S.; Flickinger, M.C.; Valla, S.; Ellingsen, T.E. Overexpression of wild-type aspartokinase increases L-lysine production in the thermotolerant methylotrophic bacterium Bacillus methanolicus. Appl. Environ. Microbiol. 2009, 75, 652-661. [CrossRef] [PubMed]

92. Nærdal, I.; Brautaset, T.; Pfeifenschneider, J.; Wendisch, V.W. Methanol-based cadaverine production by genetically engineered Bacillus methanolicus strains. Microb. Biotechnol. 2015, 8, 342-350. [CrossRef] [PubMed]

93. Irla, M.; Nærdal, I.; Brautaset, T.; Wendisch, V.F. Methanol-based $\gamma$-aminobutyric acid (GABA) production by genetically engineered Bacillus methanolicus strains. Ind. Crop. Prod. 2017, 106, 12-20. [CrossRef]

94. Titok, M.A.; Chapuis, J.; Selezneva, Y.V.; Lagodich, A.V.; Prokulevich, V.A.; Ehrlich, S.D.; Janniere, L. Bacillus subtilis soil isolates: Plasmid replicon analysis and construction of a new theta-replicating vector. Plasmid 2003, 49, 53-62. [CrossRef]

95. Mee, E.K.; Welker, N.E. Development of Genetic Tools to Analyze and Characterize Genes of the Thermophile Geobacillus stearothermophilus. In Unpublished; NCBI GenBank: Bethesda, MD, USA, 2003.

96. Olson, D.G.; Lynd, L.R. Computational design and characterization of a temperature-sensitive plasmid replicon for gram positive thermophiles. J. Biol. Eng. 2012, 6, 5. [CrossRef] [PubMed]

97. Joseph, P.; Fantino, J.R.; Herbaud, M.L.; Denizot, F. Rapid orientated cloning in a shuttle vector allowing modulated gene expression in Bacillus subtilis. FEMS Microbiol. Lett. 2001, 205, 91-97. [CrossRef] [PubMed] 
98. Stragier, P.; Bonamy, C.; Karmazyn-Campelli, C. Processing of a sporulation sigma factor in Bacillus subtilis: How morphological structure could control gene expression. Cell 1988, 52, 697-704. [CrossRef]

99. Nguyen, H.D.; Nguyen, Q.A.; Ferreira, R.C.; Ferreira, L.C.; Tran, L.T.; Schumann, W. Construction of plasmid-based expression vectors for Bacillus subtilis exhibiting full structural stability. Plasmid 2005, 54, 241-248. [CrossRef] [PubMed]

100. Hussein, A.H.; Lisowska, B.K.; Leak, D.J. The genus Geobacillus and their biotechnological potential. Adv. Appl. Microbiol. 2015, 92, 1-48. [PubMed]

101. Kananaviciute, R.; Citavicius, D. Genetic engineering of Geobacillus spp. J. Microbiol. Methods 2015, 111, 31-39. [CrossRef] [PubMed]

102. Imanaka, T.; Fujii, M.; Aramori, I.; Aiba, S. Transformation of Bacillus stearothermophilus with plasmid DNA and characterization of shuttle vector plasmids between Bacillus stearothermophilus and Bacillus subtilis. J. Bacteriol. 1982, 149, 824-830. [PubMed]

103. Tominaga, Y.; Ohshiro, T.; Suzuki, H. Conjugative plasmid transfer from Escherichia coli is a versatile approach for genetic transformation of thermophilic Bacillus and Geobacillus species. Extremophiles 2016, 20, 375-381. [CrossRef] [PubMed]

104. Lin, L.; Xu, J. Dissecting and engineering metabolic and regulatory networks of thermophilic bacteria for biofuel production. Biotechnol. Adv. 2013, 31, 827-837. [CrossRef] [PubMed]

105. Rygus, T.; Hillen, W. Inducible high-level expression of heterologous genes in Bacillus megaterium using the regulatory elements of the xylose-utilization operon. Appl. Microbiol. Biotechnol. 1991, 35, 594-599. [CrossRef] [PubMed]

106. Mougiakos, I.; Mohanraju, P.; Bosma, E.F.; Vrouwe, V.; Finger Bou, M.; Naduthodi, M.I.S.; Gussak, A.; Brinkman, R.B.L.; van Kranenburg, R.; van der Oost, J. Characterizing a thermostable Cas9 for bacterial genome editing and silencing. Nat. Commun. 2017, 8, 1647. [CrossRef] [PubMed]

107. Qiu, Y.; Xiao, F.; Wei, X.; Wen, Z.; Chen, S. Improvement of lichenysin production in Bacillus licheniform is by replacement of native promoter of lichenysin biosynthesis operon and medium optimization. Appl. Microbiol. Biotechnol. 2014, 98, 8895-8903. [CrossRef] [PubMed]

108. Pogrebnyakov, I.; Jendresen, C.B.; Nielsen, A.T. Genetic toolbox for controlled expression of functional proteins in Geobacillus spp. PLoS ONE 2017, 12, e0171313. [CrossRef] [PubMed]

109. Kovacs, A.T.; van Hartskamp, M.; Kuipers, O.P.; van Kranenburg, R. Genetic tool development for a new host for biotechnology, the thermotolerant bacterium Bacillus coagulans. Appl. Environ. Microbiol. 2010, 76, 4085-4088. [CrossRef] [PubMed]

110. Bosma, E.F.; van de Weijer, A.H.; van der Vlist, L.; de Vos, W.M.; van der Oost, J.; van Kranenburg, R. Establishment of markerless gene deletion tools in thermophilic Bacillus smithii and construction of multiple mutant strains. Microb. Cell Factories 2015, 14, 99. [CrossRef] [PubMed]

111. Wang, P.Z.; Doi, R.H. Overlapping promoters transcribed by Bacillus subtilis sigma 55 and sigma 37 RNA polymerase holoenzymes during growth and stationary phases. J. Biol. Chem. 1984, 259, 8619-8625. [PubMed]

112. Qi, G.; Kang, Y.; Li, L.; Xiao, A.; Zhang, S.; Wen, Z.; Xu, D.; Chen, S. Deletion of meso-2,3-butanediol dehydrogenase gene $b u d C$ for enhanced D-2,3-butanediol production in Bacillus licheniformis. Biotechnol. Biofuels 2014, 7, 16. [CrossRef] [PubMed]

113. Zhan, Y.; Zhu, C.; Sheng, B.; Cai, D.; Wang, Q.; Wen, Z.; Chen, S. Improvement of glycerol catabolism in Bacillus licheniformis for production of poly-gamma-glutamic acid. Appl. Microbiol. Biotechnol. 2017, 101, 7155-7164. [CrossRef] [PubMed]

114. Wei, X.; Zhou, Y.; Chen, J.; Cai, D.; Wang, D.; Qi, G.; Chen, S. Efficient expression of nattokinase in Bacillus licheniformis: Host strain construction and signal peptide optimization. J. Ind. Microbiol. Biotechnol. 2015, 42, 287-295. [CrossRef] [PubMed]

115. Nakano, M.M.; Magnuson, R.; Myers, A.; Curry, J.; Grossman, A.D.; Zuber, P. Srfa is an operon required for surfactin production, competence development, and efficient sporulation in Bacillus subtilis. J. Bacteriol. 1991, 173, 1770-1778. [CrossRef] [PubMed]

116. Taylor, M.P.; van Zyl, L.; Tuffin, I.M.; Leak, D.J.; Cowan, D.A. Genetic tool development underpins recent advances in thermophilic whole-cell biocatalysts. Microb. Biotechnol. 2011, 4, 438-448. [CrossRef] [PubMed] 
117. Zeldes, B.M.; Keller, M.W.; Loder, A.J.; Straub, C.T.; Adams, M.W.; Kelly, R.M. Extremely thermophilic microorganisms as metabolic engineering platforms for production of fuels and industrial chemicals. Front. Microbiol. 2015, 6, 1209. [CrossRef] [PubMed]

118. Haima, P.; Bron, S.; Venema, G. The effect of restriction on shotgun cloning and plasmid stability in Bacillus subtilis Marburg. Mol. Gen. Genet. 1987, 209, 335-342. [CrossRef] [PubMed]

119. Zhou, J.; Wu, K.; Rao, C.V. Evolutionary engineering of Geobacillus thermoglucosidasius for improved ethanol production. Biotechnol. Bioeng. 2016, 113, 2156-2167. [CrossRef] [PubMed]

120. Van Kranenburg, R.; van hartskamp, M.; Anthonius, E.; Heintz, J.; Van Mullekom, E.J.G.; Snelders, J. Method of Preparation of a Compound Using a Genetically Modified Homolactic Thermophilic Bacilli. U.S. Patent 8,802.403 B2, 12 August 2014.

121. Suzuki, H.; Taketani, T.; Kobayashi, J.; Ohshiro, T. Antibiotic resistance mutations induced in growing cells of Bacillus-related thermophiles. J. Antibiot. 2018, 71, 382-389. [CrossRef] [PubMed]

122. Peteranderl, R.; Shotts, E.B., Jr.; Wiegel, J. Stability of antibiotics under growth conditions for thermophilic anaerobes. Appl. Environ. Microbiol. 1990, 56, 1981-1983. [PubMed]

123. Liao, H.; McKenzie, T.; Hageman, R. Isolation of a thermostable enzyme variant by cloning and selection in a thermophile. Proc. Natl. Acad. Sci. USA 1986, 83, 576-580. [CrossRef] [PubMed]

124. Lipscomb, G.L.; Conway, J.M.; Blumer-Schuette, S.E.; Kelly, R.M.; Adams, M.W. A Highly Thermostable Kanamycin Resistance Marker Expands the Tool Kit for Genetic Manipulation of Caldicellulosiruptor bescii. Appl. Environ. Microbiol. 2016, 82, 4421-4428. [CrossRef] [PubMed]

125. Hoseki, J.; Yano, T.; Koyama, Y.; Kuramitsu, S.; Kagamiyama, H. Directed evolution of thermostable kanamycin-resistance gene: A convenient selection marker for Thermus thermophilus. J. Biochem. 1999, 126, 951-956. [CrossRef] [PubMed]

126. Mougiakos, I.; Bosma, E.F.; Weenink, K.; Vossen, E.; Goijvaerts, K.; van der Oost, J.; van Kranenburg, R. Efficient Genome Editing of a Facultative Thermophile Using Mesophilic spCas9. ACS Synth. Biol. 2017, 6, 849-861. [CrossRef] [PubMed]

127. Brouns, S.J.; Wu, H.; Akerboom, J.; Turnbull, A.P.; de Vos, W.M.; van der Oost, J. Engineering a selectable marker for hyperthermophiles. J. Biol. Chem. 2005, 280, 11422-11431. [CrossRef] [PubMed]

128. Nakamura, A.; Takakura, Y.; Kobayashi, H.; Hoshino, T. In vivo directed evolution for thermostabilization of Escherichia coli hygromycin B phosphotransferase and the use of the gene as a selection marker in the host-vector system of Thermus thermophilus. J. Biosci. Bioeng. 2005, 100, 158-163. [CrossRef] [PubMed]

129. Wada, K.; Kobayashi, J.; Furukawa, M.; Doi, K.; Ohshiro, T.; Suzuki, H. A thiostrepton resistance gene and its mutants serve as selectable markers in Geobacillus kaustophilus HTA426. Biosci. Biotechnol. Biochem. 2016, 80, 368-375. [CrossRef] [PubMed]

130. Muhammad, S.; Ali, A.; Naz, A.; Hassan, A.; Riaz, N.; Saeed-ul-Hassan, S.; Andleeb, S.; Barh, D. A New Broad-Spectrum Peptide Antibiotic Produced by Bacillus brevis Strain MH9 Isolated from Margalla Hills of Islamabad, Pakistan. Int. J. Pept. Res. Ther. 2016, 22, 271-279. [CrossRef]

131. Muhammad, S.A.; Ahmed, S. Production and characterization of a new antibacterial peptide obtained from Aeribacillus pallidus SAT4. Biotechnol. Rep. 2015, 8, 72-80. [CrossRef] [PubMed]

132. Pueyo, M.T.; Bloch, C., Jr.; Carmona-Ribeiro, A.M.; di Mascio, P. Lipopeptides produced by a soil Bacillus megaterium strain. Microb. Ecol. 2009, 57, 367-378. [CrossRef] [PubMed]

133. Martirani, L.; Varcamonti, M.; Naclerio, G.; De Felice, M. Purification and partial characterization of bacillocin 490, a novel bacteriocin produced by a thermophilic strain of Bacillus licheniformis. Microb. Cell Fact. 2002, 1, 1. [CrossRef] [PubMed]

134. Garg, N.; Tang, W.; Goto, Y.; Nair, S.K.; van der Donk, W.A. Lantibiotics from Geobacillus thermodenitrificans. Proc. Natl. Acad. Sci. USA 2012, 109, 5241-5246. [CrossRef] [PubMed]

135. Pollock, M.R. Pollock 1965.pdf. Biochem. J. 1965, 94, 666-675. [CrossRef] [PubMed]

136. Rhazi-Filali, F.; Zaid, A.; Ledent, P.; Vanhove, M.; van Beeumen, J.; Frère, J.-M. A $\beta$-lactamase produced by a thermophilic Bacillus. FEMS Microbiol. Lett. 1996, 140, 61-64. [CrossRef]

137. Bingham, A.H.; Bruton, C.J.; Atkinson, T. Isolation and partial characterization of four plasmids from antibiotic-resistant thermophilic bacilli. J. Gen. Microbiol. 1979, 114, 401-408. [CrossRef] [PubMed]

138. Imanaka, T.; Fujii, M.; Aiba, S. Isolation and characterization of antibiotic resistance plasmids from thermophilic bacilli and construction of deletion plasmids. J. Bacteriol. 1981, 146, 1091-1097. [PubMed] 
139. Matsumura, M.; Katakura, Y.; Imanaka, T.; Aiba, S. Enzymatic and nucleotide sequence studies of a kanamycin-inactivating enzyme encoded by a plasmid from thermophilic bacilli in comparison with that encoded by plasmid pUB110. J. Bacteriol. 1984, 160, 413-420. [PubMed]

140. Poli, A.; Finore, I.; Romano, I.; Gioiello, A.; Lama, L.; Nicolaus, B. Microbial Diversity in Extreme Marine Habitats and Their Biomolecules. Microorganisms 2017, 5. [CrossRef]

141. Vakhlu, J.; Sudan, A.K.; Johri, B.N. Metagenomics: Future of microbial gene mining. Indian J. Microbiol. 2008, 48, 202-215. [CrossRef] [PubMed]

142. Maugeri, T.L.; Gugliandolo, C.; Caccamo, D.; Stackebrandt, E. A polyphasic taxonomic study of thermophilic bacilli from shallow, marine vents. Syst. Appl. Microbiol. 2001, 24, 572-587. [CrossRef] [PubMed]

143. Arena, A.; Maugeri, T.L.; Pavone, B.; Iannello, D.; Gugliandolo, C.; Bisignano, G. Antiviral and immunoregulatory effect of a novel exopolysaccharide from a marine thermotolerant Bacillus licheniformis. Int. Immunopharmacol. 2006, 6, 8-13. [CrossRef] [PubMed]

144. Elbehery, A.H.; Leak, D.J.; Siam, R. Novel thermostable antibiotic resistance enzymes from the Atlantis II Deep Red Sea brine pool. Microb. Biotechnol. 2017, 10, 189-202. [CrossRef] [PubMed]

145. Suzuki, H.; Murakami, A.; Yoshida, K. Counterselection system for Geobacillus kaustophilus HTA426 through disruption of pyrF and pyrR. Appl. Environ. Microbiol. 2012, 78, 7376-7383. [CrossRef] [PubMed]

146. Cubitt, A.B.; Heim, R.; Adams, S.R.; Boyd, A.E.; Gross, L.A.; Tsien, R.Y. Understanding, improving and using green fluorescent proteins. Trends Biochem. Sci. 1995, 20, 448-455. [CrossRef]

147. Cava, F.; de Pedro, M.A.; Blas-Galindo, E.; Waldo, G.S.; Westblade, L.F.; Berenguer, J. Expression and use of superfolder green fluorescent protein at high temperatures in vivo: A tool to study extreme thermophile biology. Environ. Microbiol. 2008, 10, 605-613. [CrossRef] [PubMed]

148. Wingen, M.; Jaeger, K.E.; Gensch, T.; Drepper, T. Novel Thermostable Flavin-binding Fluorescent Proteins from Thermophilic Organisms. Photochem. Photobiol. 2017, 93, 849-856. [CrossRef] [PubMed]

149. Jensen, T.O.; Pogrebnyakov, I.; Falkenberg, K.B.; Redl, S.; Nielsen, A.T. Application of the thermostable beta-galactosidase, BgaB, from Geobacillus stearothermophilus as a versatile reporter under anaerobic and aerobic conditions. AMB Express 2017, 7, 169. [CrossRef] [PubMed]

150. Bartosiak-Jentys, J.; Eley, K.; Leak, D.J. Application of pheB as a reporter gene for Geobacillus spp., enabling qualitative colony screening and quantitative analysis of promoter strength. Appl. Environ. Microbiol. 2012, 78, 5945-5947. [CrossRef] [PubMed]

151. Kostner, D.; Rachinger, M.; Liebl, W.; Ehrenreich, A. Markerless deletion of putative alanine dehydrogenase genes in Bacillus licheniformis using a codBA-based counterselection technique. Microbiology 2017, 163, 1532-1539. [CrossRef] [PubMed]

152. Hertel, R.; Volland, S.; Liesegang, H. Conjugative reporter system for the use in Bacillus licheniformis and closely related Bacilli. Lett. Appl. Microbiol. 2015, 60, 162-167. [CrossRef] [PubMed]

153. Deltcheva, E.; Chylinski, K.; Sharma, C.M.; Gonzales, K.; Chao, Y.; Pirzada, Z.A.; Eckert, M.R.; Vogel, J.; Charpentier, E. CRISPR RNA maturation by trans-encoded small RNA and host factor RNase III. Nature 2011, 471, 602-607. [CrossRef] [PubMed]

154. Li, K.; Cai, D.; Wang, Z.; He, Z.; Chen, S. Development of an Efficient Genome Editing Tool in Bacillus licheniformis Using CRISPR-Cas9 Nickase. Appl. Environ. Microbiol. 2018. [CrossRef] [PubMed]

(C) 2018 by the authors. Licensee MDPI, Basel, Switzerland. This article is an open access article distributed under the terms and conditions of the Creative Commons Attribution (CC BY) license (http://creativecommons.org/licenses/by/4.0/). 